\title{
OSTEOHISTOLOGY OF THE HADROSAUROID (DINOSAURIA: ORNITHOPODA) FROM LABIRINTA CAVE, BULGARIA: AN EXAMPLE OF INSULAR DWARFISM OR SIMPLY YOUNG GIANT?'
}

\author{
Vladimir Nikolov ${ }^{1 i i}$
}

1 Department of Geology, Paleontology and Fossil Fuels, Sofia University, Sofia, 1504, Bulgaria

vlado_raptor@mail.bg

\section{INTRODUCTION}

The fossils of non-avian dinosaurs in Bulgaria are rare. Most of them come from two fossiliferous locations inside the Labirinta cave (Vratza district, Northwestern Bulgaria), which is formed in the upper Maastrichtian limestones of the Kajlâka Formation. Labirinta's dinosaur material is described as pertaining to hadrosauroid ornithopod (Godefroit and Motchurova-Dekova, 2010). Interesting characteristic of the hadrosauroid bones is their small size, but, as noted by Godefroit and Motchurova-Dekova (2010), without osteohistological data it is not possible to affirm whether they belong to young individual/s or to small-sized adult animal/s. This problem is of interest due to the presence of ornithopods on the islands of the latest Cretaceous European archipelago which are thought to be an example for insular dwarfism. Herein I present information about the long bone histology of the Bulgarian hadrosauroid and test the hypothesis that this ornithopod is an island dwarf.

\section{MATERIAL AND METHODS}

One partial diaphysis and six bone fragments found in association with the fossil material described by Godefroit and Motchurova-Dekova (2010) were transversely sectioned (Fig. 1). Thin-sections were then prepared following standard paleohistological methods (Chinsamy and Raath, 1992; Wilson, 1994), with some changes in the methodology due to limitations imposed by available tools and material (Fig. 2). The application of the less destructive Histological Coring Method (Stein and Sander, 2009) was not viable option because of the extremely fragmentary nature of the studied material.

\footnotetext{
${ }^{\mathbf{i}}$ The following content (text and figures) represents slightly modified version (featuring minor alterations which aim to improve the grammar and readability, but with no changes to the general structure of the original text) of a poster presentation which was featured in the program of the $3^{\text {rd }}$ International Symposuim on Paleohistology, held in Bonn, Germany, in 2015. The original citation of this work is as follows: Nikolov, V. 2015. Osteohistology of the hadrosauroid (Dinosauria: Ornithopoda) from Labirinta cave, Bulgaria: An example of insular dwarfism or simply young giant? $3^{\text {rd }}$ International Symposium on Paleohistology, Program and Abstracts: p. 97. All of the interpretations presented herein are based on raw data and are yet to be subjected to peer-review.

${ }^{\text {ii }}$ The author is currently not affiliated with the Sofia University. Provided e-mail contact is still valid.
} 


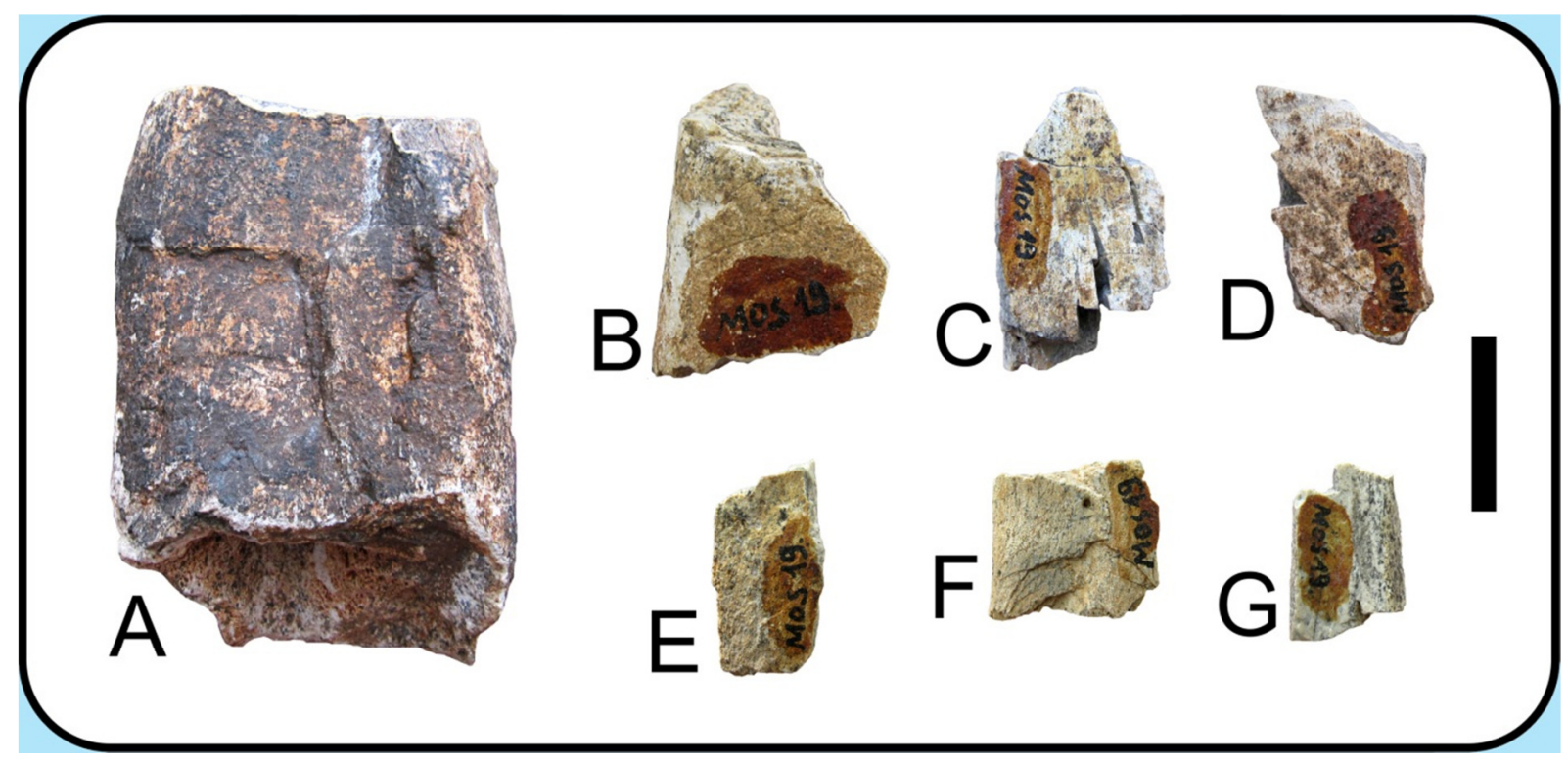

Figure 1. Studied hadrosauroid fossil bone fragments from Labirinta cave (Vratza district, NW Bulgaria). (A) Fragmentary diaphysis NMNHS F31442. (B) Bone fragment NMNHS Mos19-1. (C) Bone fragment NMNHS Mos19-2. (D) Bone fragment NMNHS Mos19-3. (E) Bone fragment NMNHS Mos19-4. (F) Bone fragment NMNHS Mos19-5. (G) Bone fragment NMNHS Mos19-6. Scale bar: $3 \mathrm{~cm}$.

Jessica Mitchell and Martin P. Sander (both from IPB) kindly provided high-resolution scanned images of thin-sections from 3 femora, 2 tibiae and 3 humeri of the basal hadrosaur Telmatosaurus, and 4 femora and 3 humeri of the rhabdodontid Zalmoxes. These images were used as comparative material.

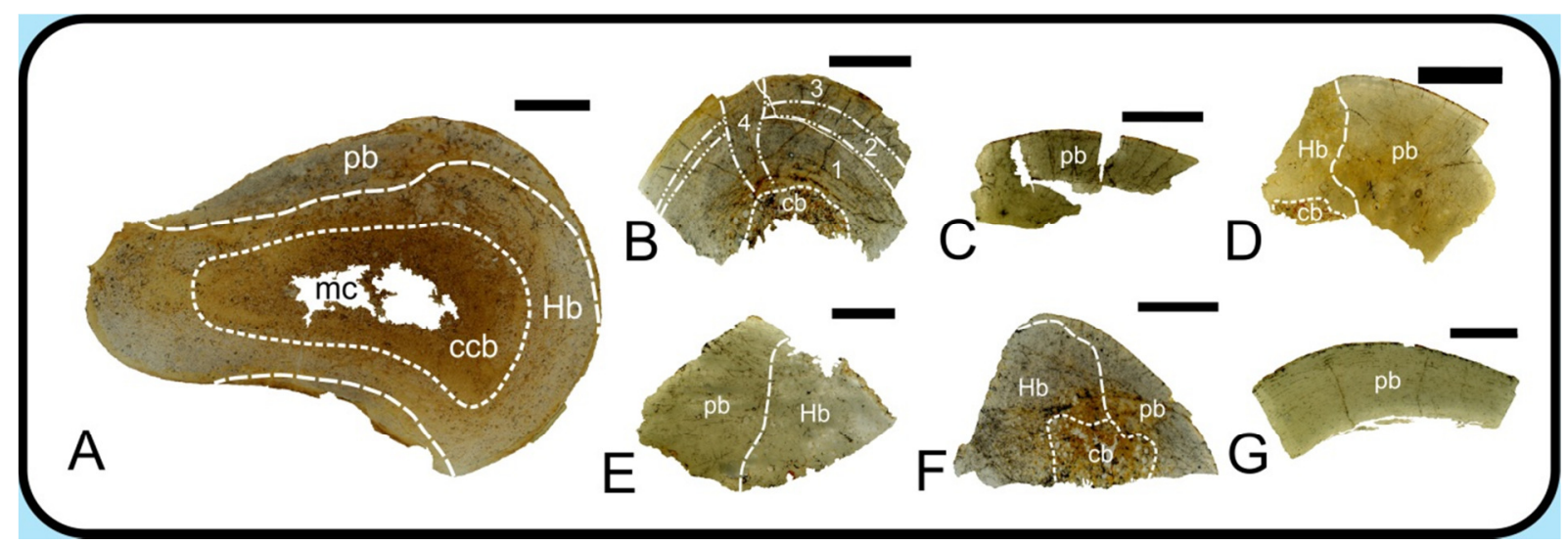

Figure 2. Transverse thin-sections of the hadrosauroid fossil bone fragments from Labirinta cave (Vratza district, NW Bulgaria). (A) NMNHS F31442. (B) NMNHS Mos19-1 (numbers mark zones with distinct vascularization patterns). (C) NMNHS Mos19-2. (D) NMNHS Mos19-3. (E) NMNHS Mos19-4. (F) NMNHS Mos19-5. (G) NMNHS Mos19-6. cb - cancellous bone, ccb - compacted cancellous bone, Hb - Haversian bone, mc - medullary cavity, pb - periosteal bone. 1 - first zone with laminar bone, 2 - zone with mostly reticular bone, 3 - second zone with laminar bone, 4 - zone with reticular bone. Scale bar: (A-D, F) $1 \mathrm{~cm},(\mathrm{E}, \mathrm{G}) 5 \mathrm{~mm}$. 
Information about the studied specimens is provided in Table 1. The ostehistology of the Bulgarian hadrosauroid was observed and studied with Leica DM2500 microscope under plane-polarized and cross-polarized light.

\begin{tabular}{|c|c|c|c|c|}
\hline Specimen & Taxon & Skeletal element & Length & Locality \\
\hline NMNHS F31442 & ?Hadrosauroidea & $\begin{array}{c}\text { fragmentary } \\
\text { diaphysis }\end{array}$ & $\begin{array}{c}9.8 \mathrm{~cm} \\
\text { (incomplete) }\end{array}$ & $\begin{array}{c}\text { Labirinta cave, } \\
\text { Bulgaria }\end{array}$ \\
\hline NMNHS Mos19-1 & ?Hadrosauroidea & bone fragment & 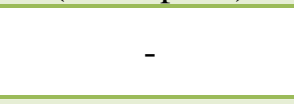 & $\begin{array}{c}\text { Labirinta cave, } \\
\text { Bulgaria }\end{array}$ \\
\hline NMNHS Mos19-2 & ?Hadrosauroidea & bone fragment & - & $\begin{array}{c}\text { Labirinta cave, } \\
\text { Bulgaria }\end{array}$ \\
\hline NMNHS Mos19-3 & ?Hadrosauroidea & bone fragment & - & $\begin{array}{c}\text { Labirinta cave, } \\
\text { Bulgaria }\end{array}$ \\
\hline NMNHS Mos19-4 & ?Hadrosauroidea & bone fragment & - & $\begin{array}{c}\text { Labirinta cave, } \\
\text { Bulgaria }\end{array}$ \\
\hline NMNHS Mos19-5 & ?Hadrosauroidea & bone fragment & - & $\begin{array}{c}\text { Labirinta cave, } \\
\text { Bulgaria }\end{array}$ \\
\hline NMNHS Mos19-6 & ?Hadrosauroidea & bone fragment & - & $\begin{array}{c}\text { Labirinta cave, } \\
\text { Bulgaria }\end{array}$ \\
\hline MAFI OB3130 & Telmatosaurus & femur, right & $46.6 \mathrm{~cm}$ (est.) & Valiora, Romania \\
\hline FGGUB R1832 & Telmatosaurus & femur, left & $25 \mathrm{~cm}$ & Simpetru, Romania \\
\hline FGGUB R1981 & Telmatosaurus & femur, left & hatchling & - \\
\hline MAFI OB3129 & Telmatosaurus & tibia & $\begin{array}{c}26.5 \mathrm{~cm} \\
\text { (incomplete) }\end{array}$ & 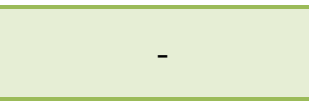 \\
\hline FGGUB R7 & Telmatosaurus & tibia, left & $45 \mathrm{~cm}$ (est.) & Duparau, Romania \\
\hline FGGUB R1850 & Telmatosaurus & humerus, right & hatchling & - \\
\hline MAFI OB3126 & Telmatosaurus & humerus, left & $32.5 \mathrm{~cm}$ (est.) & Valiora, Romania \\
\hline FGGUB R1985 & Telmatosaurus & humerus, right & $\begin{array}{c}14 \mathrm{~cm}(35 \mathrm{~cm} \mathrm{-} \\
\text { est. })\end{array}$ & Gropa, Romania \\
\hline FGGUB R1382 & Zalmoxes robustus & femur, left & $28 \mathrm{~cm}$ (est.) & Carare, Romania \\
\hline FGGUB R1002 & Zalmoxes robustus & femur & $32 \mathrm{~cm}$ (est.) & Simpetru, Romania \\
\hline FGGUB R1088 & $\begin{array}{c}\text { Zalmoxes } \\
\text { shqiperorum }\end{array}$ & femur, left & $16.4 \mathrm{~cm}$ (est.) & Valiora, Romania \\
\hline FGGUB R1608 & $\begin{array}{c}\text { Zalmoxes } \\
\text { shqiperorum }\end{array}$ & femur, left & $33.3 \mathrm{~cm}$ & Turka, Romania \\
\hline FGGUB R6 & Zalmoxes robustus & humerus, right & $18 \mathrm{~cm}$ (est.) & Duparau, Romania \\
\hline FGGUB R1392 & Zalmoxes robustus & humerus, right & $\begin{array}{c}9.3 \mathrm{~cm} \mathrm{(20.1} \mathrm{cm} \mathrm{-} \\
\text { est.) }\end{array}$ & Carare, Romania \\
\hline FGGUB OB3077 & Zalmoxes sp. & humerus, left & $25.5 \mathrm{~cm}$ & Valiora, Romania \\
\hline
\end{tabular}

Table 1. List with the studied fossil specimens and information about their taxonomy, size, and locality.

\section{RESULTS}

Thin-sections reveal that the cortex of all 7 specimens is built of highly vascularized tissues of the woven-parallel complex. Vascularization patterns differ in different areas of the 
cortex but the predominating model is of laminary organized primary osteons. Where present the laminar bone tissue is more than $5 \mathrm{~mm}$ in thickness (in specimens which preserve sufficient part of the cortex, it may have thickness of about $1 \mathrm{~cm}$, or more). In NMNHS Mos19-5 and in the deep cortex of NMNHS Mos19-1 the laminar organization of the vascular system is result of circumferential rows of longitudinal primary osteons (Fig. 3).

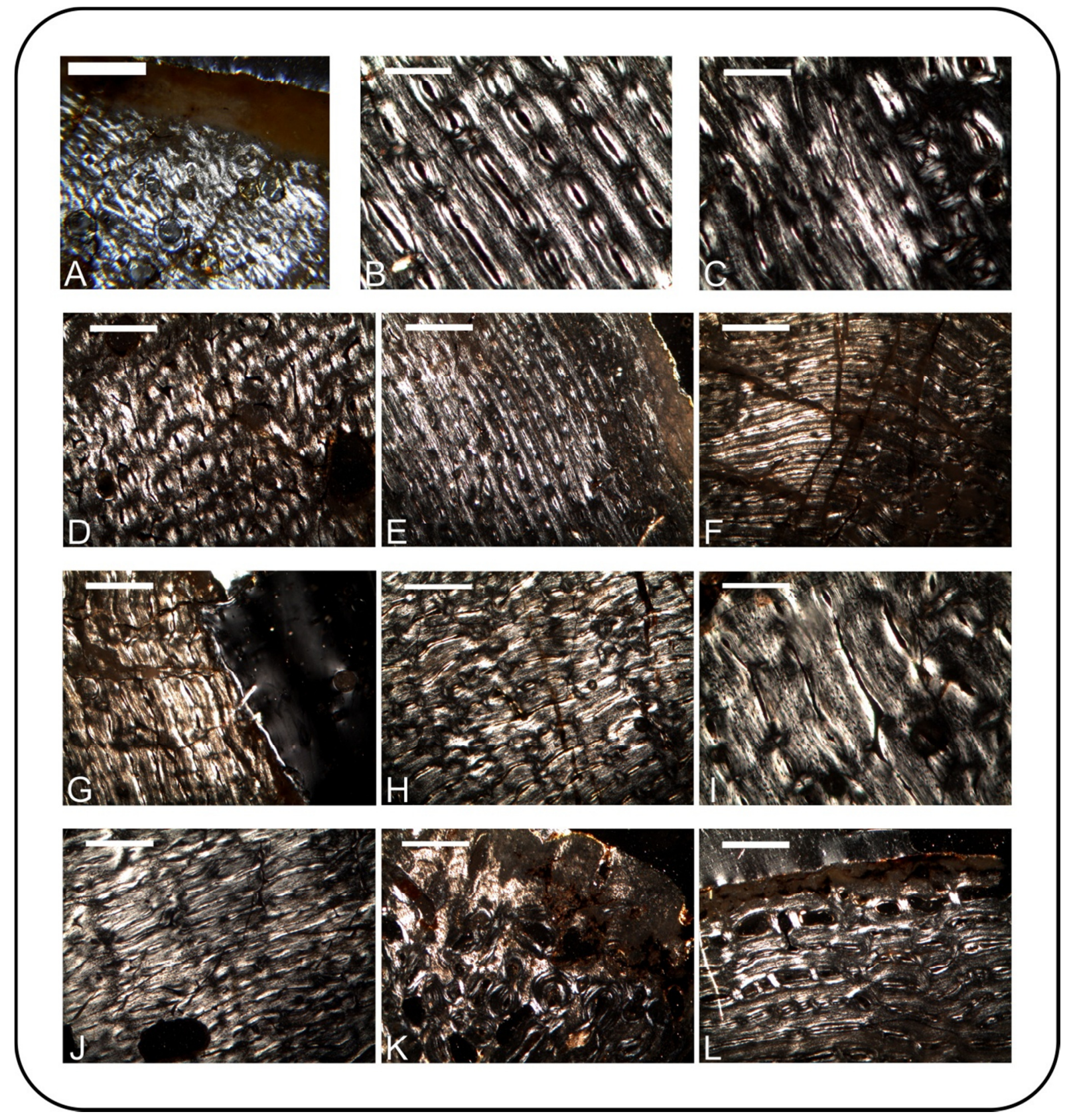

Figure 3. Primary bone tissues in the cortex of the studied bone fragments of the Bulgarian hadrosauroid in cross-polarized light. (A) Woven-parallel bone tissue in the outer cortex of NMNHS F31442. (B) Wovenparallel laminar bone tissue in the deep cortex of NMNHS Mos19-1. (C) Woven-parallel bone tissue in the middle cortex of NMNHS Mos19-1, at the boundary between zone 1 and zone 2. (D) Woven-parallel reticular bone tissue in the middle cortex of NMNHS Mos19-1. (E) Woven-parallel laminar bone tissue in the outer cortex of NMNHS Mos19-1. (F) Woven-parallel laminar bone tissue in the outer cortex of NMNHS Mos19-2. (G) Woven-parallel laminar bone tissue in the outer cortex of NMNHS Mos19-2. (H) Woven-parallel laminar 
bone tissue in the middle cortex of NMNHS Mos19-3. (I) Woven-parallel laminar bone tissue in the middle cortex of NMNHS Mos19-3. (J) Woven-parallel laminar bone tissue in the deep cortex of NMNHS Mos19-4. (K) Radially vascularized parallel-fibered bone in the outermost cortex of NMNHS Mos19-5. (L) Wovenparallel laminar bone tissue in the outermost cortex of NMNHS Mos19-6. Scale bar: (A) $1 \mathrm{~mm}$, (B, C, I) 200 $\mu \mathrm{m},(\mathrm{D}-\mathrm{H}, \mathrm{J}-\mathrm{L}) 500 \mu \mathrm{m}$.

The bone matrix consists almost entirely of parallel-fibered or lamellar bone tissue. Woven component is usually in higher quantity around longitudinal primary osteons, especially in the deep cortex (Fig. 3).

The cortical tissues of all studied specimens are affected by processes of resorption and/or secondary remodeling in various degrees. Locally dense Haversian bone is present up to the subperiosteal cortex (Fig. 4). The number of generations of secondary osteons is typically up to 3 , but it could reach 5 .

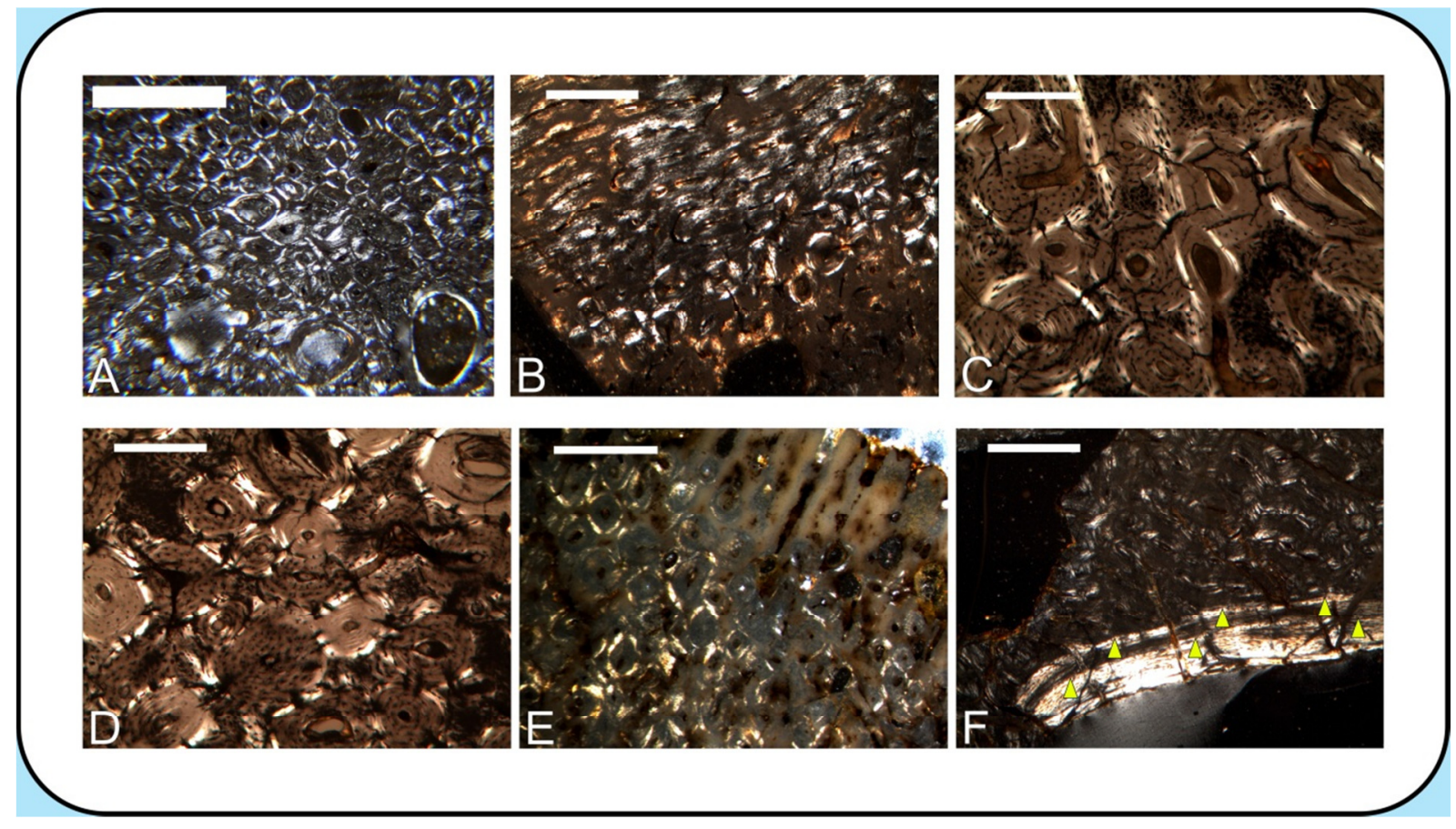

Figure 4. Secondary bone tissues in the cortex of the studied bone fragments of the Bulgarian hadrosauroid in cross-polarized light. (A) Dense Haversian bone in the middle and outer cortex of NMNHS F31442. (B) Secondary osteons locally developed in zone 2 of the cortex of NMNHS Mos19-1. (C) Dense Haversian bone in the cortex of NMNHS Mos19-3. Note the difference in histological and cellular characteristics of the secondary osteons from different generations. Nicols are crossed at angle allowing maximum visibility of tissue characteristics. (D) Dense Haversian bone in the cortex of NMNHS Mos19-4. Note the difference in histological and cellular characteristics of the secondary osteons from different generations. Nicols are crossed at angle allowing maximum visibility of tissue characteristics. (E) Haversian bone in the outermost cortex of NMNHS Mos19-5. (F) Two generations of endosteal bone in NMNHS Mos19-4. Arrow heads mark the reversal lines. Scale bar: (A) $1 \mathrm{~mm},(\mathrm{~B}, \mathrm{E}, \mathrm{F}) 500 \mu \mathrm{m},(\mathrm{C}, \mathrm{D}) 200 \mu \mathrm{m}$. 
Two generations of endosteal bone are locally developed in NMNHS Mos19-4 (Fig. 4F). With the exception of a possible line of arrested growth in the anterior cortex of NMNHS F31442 and an example of (irregular) modulation in NMNHS Mos19-1, no growth lines are observed in any of the specimens. Similarly, external fundamental system is not observed, but the bone periphery of some specimens seems to be partially eroded or is strongly affected by early diagenetic alteration.

\section{DISCUSSION}

Bone tissue vascularization of the Bulgarian hadrosauroid is very similar to that of Telmatosaurus, and differs from that of Zalmoxes and other small-sized non-hadrosauroid ornithopods. Unlike in large hadrosaurs, the laminar structure of the studied hadrosauroid remains is characterized by larger number of longitudinal primary osteons and shorter circumferential osteons. The bone matrix shows high spatial organization, a condition observed and described in Telmatosaurus and some sauropods (Benton et al, 2010; Klein et al, 2012). Presence of high amounts of parallel-fibered and lamellar bone in the wovenparallel complex is indicative of greatly reduced growth rates in the hadrosauroid from Labirinta cave compared to other hadrosaurs. While bones of Telmatosaurus show growth lines, sometimes in large number, these histological structures appear to be absent, or at least very rare, in the bones of the Bulgarian hadrosauroid, a feature which seems to be genuine and may be related to the ecology of this animal.

The transition from bone tissues with predominantly longitudinally oriented osteons to true laminar bone, the thickness of the latter, the extensive secondary bone remodeling and Haversian tissue with at least 3 generations of secondary osteons, as well as the presence of endosteal bone in one of studied specimens all suggest that the material pertains to animal/s at a late sub-adult ontogenetic stage. Although external fundamental system is not observed, based on the degree and characteristics of secondary remodeling it may be suggested that NMNHS F31442 pertains to an adult individual.

\section{CONCLUSIONS}

Bone histology suggested ontogenetic stage for the studied fossil material, and the presence of osteohistological features indicative for lowered growth rates and sometimes connected with marked decrease in body size reveal yet another dwarfed ornithopod that lived on the islands of the latest Cretaceous European archipelago, and present further example for insular dwarfism in non-avian dinosaurs.

\section{REFERENCES}

Benton, M. J., Z. Csiki, D. Grigorescu, R. Redelstorff, P. M. Sander, K. Stein, D. B. Weishampel. 2010. Dinosaurs and the island rule: The dwarfed dinosaurs from the Haţeg Island.- Palaeogeography, Palaeoclimatology, Palaeoecology, 293, 3, 438-454. doi:10.1016/j.palaeo.2010.01.026

Chinsamy, A., M. A. Raath. 1992. Preparation of bone for histological study.- Paleontologia Africana, 29, 39-44. 
Godefroit, P., N. Motchurova-Dekova. 2010. Latest Cretaceous hadrosauriod (Dinosauria: Ornithopoda) remains from Bulgaria.- Comptes Rendus Palevol, 9, 4, 163-169. doi:10.1016/j.crpv.2010.05.003

Klein, N., P. M. Sander, K. Stein, J. Le Loeuff, J. L. Carballido, E. Buffetaut. 2012. Modified laminar bone in Ampelosaurus atacis and other titanosaurs (Sauropoda): Implications for life history and physiology.- PLoS ONE, 7, 5, e36907. doi:10.1371/journal.pone.0036907

Stein, K., M. Sander. 2009. Histological core drilling: a less destructive method for studying bone histology.- Methods of fossil preparation: proceedings of the first annual Fossil Preparation and Collections Symposium, 69-80.

Wilson, J. W. 1994. Histology techniques.- In: Leiggi, P., P. May (eds.). Vertebrate Paleontological Techniques. Cambridge University Press, 205-234. 